\title{
Green tea polyphenol, epigallocatechin-3-gallate, possesses the antiviral activity necessary to fight against the hepatitis B virus replication in vitro"
}

\author{
Jing-yao PANG ${ }^{\S 1}$, Kui-jun ZHAO ${ }^{\S 1}$, Jia-bo WANG ${ }^{\dagger 2}$, Zhi-jie MA ${ }^{\dagger 1}$, Xiao-he XIAO ${ }^{3}$ \\ ( ${ }^{1}$ Clinical Pharmacy Laboratory, Beijing Friendship Hospital, Capital Medical University, Beijing 100050, China) \\ $\left({ }^{2}\right.$ China Military Institute of Chinese Medicine, 302 Military Hospital, Beijing 100039, China) \\ ('Integrative Medicine Center, 302 Military Hospital, Beijing 100039, China) \\ †E-mail: pharm_sci@126.com; 13811647091@163.com \\ Received Dec. 5, 2013; Revision accepted Mar. 16, 2014; Crosschecked May 19, 2014
}

\begin{abstract}
Although several antiviral drugs and vaccines are available for use against hepatitis B virus (HBV), hepatitis caused by HBV remains a major public health problem worldwide, which has not yet been resolved, and new anti-HBV drugs are in great demand. The present study was performed to investigate the anti-HBV activity of epigallocatechin3-gallate (EGCG), a natural-origin compound, in HepG2 2.2.15 cells. The antiviral activity of EGCG was examined by detecting the levels of HBsAg and HBeAg in the supernatant and extracellular HBV DNA. EGCG effectively suppressed the secretion of HBsAg and HBeAg from HepG2 2.2.15 cells in a dose- and time-dependent manner, and it showed stronger effects at the level of $0.11-0.44 \mu \mathrm{mol} / \mathrm{ml}(50-200 \mu \mathrm{g} / \mathrm{ml})$ than lamivudine (3TC) at $0.87 \mu \mathrm{mol} / \mathrm{ml}$ $(200 \mu \mathrm{g} / \mathrm{ml})$. EGCG also suppressed the amount of extracellular HBV DNA. The data indicated that EGCG possessed anti-HBV activity and suggested the potential of EGCG as an effective anti-HBV agent with low toxicity.
\end{abstract}

Key words: Epigallocatechin-3-gallate, Hepatitis B virus (HBV), Antiviral activity, HepG2 2.2.15, Lamivudine doi:10.1631/jzus.B1300307

\section{Introduction}

Hepatitis B caused by hepatitis B virus (HBV) is a major public health problem that has not been resolved worldwide (Pang et al., 2010), especially in China. China has the largest number of HBV-infected people in the world. Chinese patients must spend a great deal of money on drugs because of the existence of patents on state of the art antiviral compounds. Therefore, cheap compounds with identified benefits and low toxicity from natural herbal resources remain

\footnotetext{
Corresponding authors

${ }^{\S}$ The two authors contributed equally to this work

* Project supported by the National Commonweal Industry Special Research Foundation of China (No. 200807020) and the National Natural Science Foundation of China (Nos. 30973947 and 81173571) C Zhejiang University and Springer-Verlag Berlin Heidelberg 2014
}

in urgent demand.

Long-term HBV infection may develop into hepatic fibrosis, liver cirrhosis, and hepatocellular carcinoma, accounting for one million deaths annually. Increasing evidence indicates that persistent HBV infection in the liver is associated with endstage liver disease, such as cirrhosis and hepatocellular carcinoma (Park et al., 2006). Although several pharmacological therapies have been implemented to treat hepatitis B, an ultimate antiviral therapy against HBV infection has not been identified. The therapeutic effects of interferon- $\alpha$ and nucleoside analogues, such as lamivudine (3TC), entecavir, and adefovir, are not fully satisfactory because such treatments may be accompanied by side effects, drug resistance, and high costs in addition to prolonged administration (Feld and Locarnini, 2002; Perrillo, 
2005). Therefore, there is an urgent necessity to develop highly effective and easy-to-use anti-HBV drugs for the long-term treatment of HBV infection with fewer side effects and at a lower cost. Traditional Chinese medicines (TCMs) are widely used for hepatitis B in China and many different parts of the world (Zhang et al., 2010), and they may represent good candidates with special antiviral characteristics. Some TCMs and natural-origin compounds have been reported with providing promising and potent anti-HBV activities. TCMs have attracted a number of researchers who are searching for effective antiviral drugs (Stickel and Schuppan, 2007).

In our primary study, we screened some types of TCMs that have long been utilized in the treatment of chronic hepatitis in China. Additionally, diverse structural constituents in these herbs were investigated for novel anti-HBV agents. Among them, we found that epigallocatechin-3-gallate (EGCG) possessed potential antiviral activity against HBV replication and showed different characteristics from 3TC in HepG2 2.2.15 cells. EGCG (Fig. 1) belongs to the family of flavan-3-ols, and it is abundant in Camellia sinensis (green tea) and many types of medicinal herbs. EGCG has been proposed to have anti-human immunodeficiency virus type 1 (anti-HIV-1) activity (Nakane and Ono, 1989; Harada et al., 1999; Fassina et al., 2002; Yamaguchi et al., 2002). Ciesek et al. (2011) showed that EGCG inhibited viral attachment to hepatoma cells, which demonstrated that EGCG potently inhibited the hepatitis $\mathrm{C}$ virus (HCV) entry and could be part of an antiviral strategy aimed at the prevention of $\mathrm{HCV}$ reinfection after liver transplantation. However, there are no reports concerning the anti-HBV activity of EGCG. In this study, we report its activity on HBV antigen secretion and extracellular HBV DNA production in vitro.<smiles>O=C(O[C@H]1Cc2c(O)cc(O)cc2O[C@H]1c1cc(O)c(O)c(O)c1)c1cc(O)c(O)c(O)c1</smiles>

Fig. 1 Chemical structure of EGCG

\section{Materials and methods}

\subsection{EGCG and 3TC}

EGCG was purchased from the National Institutes for Food and Drug Control, Beijing, China. 3TC (purity 98\%), provided by 302 Military Hospital, Beijing, China, was used as the positive control.

\subsection{Cell culture and treatment}

The HepG2 2.2.15 cell line, which can stably produce complete virion particles and high levels of HBV proteins, was obtained from the Viral Laboratory, Institute for Infectious Diseases, 302 Military Hospital, Beijing, China. In the present study, it was used as a model of HBV-infected hepatocytes. The HepG2 2.2.15 cells were routinely cultured in Dulbecco's modified Eagle's medium (DMEM; Gibco, USA) supplemented with $10 \%(\mathrm{v} / \mathrm{v})$ fetal calf serum (Gibco, USA) and antibiotics (100 U/ml penicillin and $100 \mu \mathrm{g} / \mathrm{ml}$ streptomycin) at $37{ }^{\circ} \mathrm{C}$ in a humidified incubator at $5 \% \mathrm{CO}_{2}$, and $380 \mu \mathrm{g} / \mathrm{ml} \mathrm{G} 418$ (Gibco, USA) was added to the medium to select the HepG2 2.2.15 cell line.

HepG2 2.2.15 cells were plated at a density of $1 \times 10^{5}$ cells $/ \mathrm{ml}$ into 24 -well plates and incubated for $24 \mathrm{~h}$. Different concentrations of EGCG and 3TC were added to the medium, and a drug-free cell well was used as the control group. Cells were grown in the presence of EGCG or 3TC for $9 \mathrm{~d}$, and the supernatant was collected every other day. After incubation with EGCG or 3TC for $9 \mathrm{~d}$, the concentrations of HBsAg, HBeAg, and HBV DNA in the supernatant were determined.

\subsection{Cytotoxicity assay}

The cytotoxicity of EGCG was analyzed with MTT [3-(4,5-dimethylthiazol-2-yl)-2,5-diphenyltetrazolium bromide] assay. HepG2 2.2.15 cells were cultivated at a density of $1 \times 10^{5}$ cells/well in 96-well plates in $100 \mu \mathrm{l}$ and treated with EGCG [0.05, 0.11, 0.22, 0.44, 0.87 , or $1.74 \mu \mathrm{mol} / \mathrm{ml}$ (i.e., $25,50,100,200,400$ or $800 \mu \mathrm{g} / \mathrm{ml})]$ for $9 \mathrm{~d}$. The culture medium containing the drugs was changed every other day. On the last day, $10 \mu 1$ of MTT $(5 \mathrm{~g} / \mathrm{ml})$ was added to each well and further incubated in a $\mathrm{CO}_{2}$ incubator at $37{ }^{\circ} \mathrm{C}$ for $4 \mathrm{~h}$. The optical density (OD) at $560 \mathrm{~nm}$ was obtained. Each experiment was performed in triplicate. The cell viability was expressed as a percentage of the control. 


\subsection{Detection of HBsAg and HBeAg in the supernatant}

After incubation with EGCG or 3TC for 6 and $9 \mathrm{~d}$, the cell supernatant was collected and stored at $-80^{\circ} \mathrm{C}$ for $\mathrm{HBsAg}$ and $\mathrm{HBeAg}$ detection. $\mathrm{HBsAg}$ and $\mathrm{HBeAg}$ levels in the culture medium were determined according to the enzyme-linked immunosorbent assay (ELISA) kit instructions (Kehua Biological Technical Co., Ltd., China). The data were calculated by the following formula: inhibition of control $(\%)=$ $(1-\mathrm{ODT} / \mathrm{ODC}) \times 100 \%$, where ODT and ODC represent the cell number-adjusted OD of the test drugs and the control, respectively.

\subsection{Detection of HBV DNA by real-time quanti- tative polymerase chain reaction (qPCR)}

The quantity of HBV DNA in the culture supernatant and cells of the studied groups relative to the solvent control was determined with a 7500 fast real-time system (Applied Biosystems, USA) with TaqMan technology. The supernatant of the cells cultured for 6 and $9 \mathrm{~d}$ was collected, and the DNA was extracted from $200 \mu \mathrm{l}$ of medium using the QIAamp DNA Mini Kit (QIAGEN GmbH, Germany) according to the manufacturer's recommendations. The HBV DNA sequence was amplified with a forward primer (5'-ACTCGTGGTGGACTTCTCTCAA TT-3'), a reverse primer (5'-CGCAGACACATCC AGCATA-3'), and a fluorogenic TaqMan probe (FAM5'-AGTCCCCAACCTCCAATCACTCACCA3'TAMRA). The internal control was $\beta$-actin, and it was amplified with a forward primer (5'-GGAAA TCGTGCGTGACATTAAG-3'), a reverse primer (5'GCTCATTGCCAATGGTGATG-3'), and a TaqMan probe (FAM5'-TACGTCGCCCTGGACTTCGAGCA$3^{\prime}$ TAMRA). The cycling program was $50{ }^{\circ} \mathrm{C}$ for $2 \mathrm{~min}, 95^{\circ} \mathrm{C}$ for $10 \mathrm{~min}$, and 40 cycles of $95^{\circ} \mathrm{C}$ for $15 \mathrm{~s}$ and $60{ }^{\circ} \mathrm{C}$ for $1 \mathrm{~min}$. The data were calculated by the following formula: inhibition of control $(\%)=$ $(1-\mathrm{ET} / \mathrm{EC}) \times 100 \%$, where ET and EC represent the HBV DNA expression of the test drugs and the drug control, respectively.

\subsection{Statistical analysis}

All of the experiments in this study were repeated at least three times, and the results are expressed as the mean \pm standard deviation (SD). Statis- tical significance was determined using an analysis of variance (ANOVA). Differences were considered to be significant at $P<0.05$.

\section{Results}

\subsection{Cytotoxic effects of EGCG on HepG2 2.2.15 cells}

The viabilities of HepG2 2.2.15 cells in the presence of various concentrations [0.05, 0.11, 0.22, $0.44,0.87$, and $1.74 \mu \mathrm{mol} / \mathrm{ml}$ (i.e., $25,50,100,200$, 400 , and $800 \mu \mathrm{g} / \mathrm{ml})$ ] of EGCG were determined with an MTT assay. The results showed that EGCG below $0.87 \mu \mathrm{mol} / \mathrm{ml}$ had no significant toxicity in $\mathrm{HepG} 2$ 2.2.15 cells (Fig. 2), and the cell viability relative to the control was as high as $80 \%$. However, concentrations of EGCG higher than $1.74 \mu \mathrm{mol} / \mathrm{ml}$ may be cytotoxic in HepG2 2.2.15 cells. The cytotoxicity of EGCG was examined to determine the treatment concentrations in the subsequent HepG2 2.2.15 cell culture experiments.

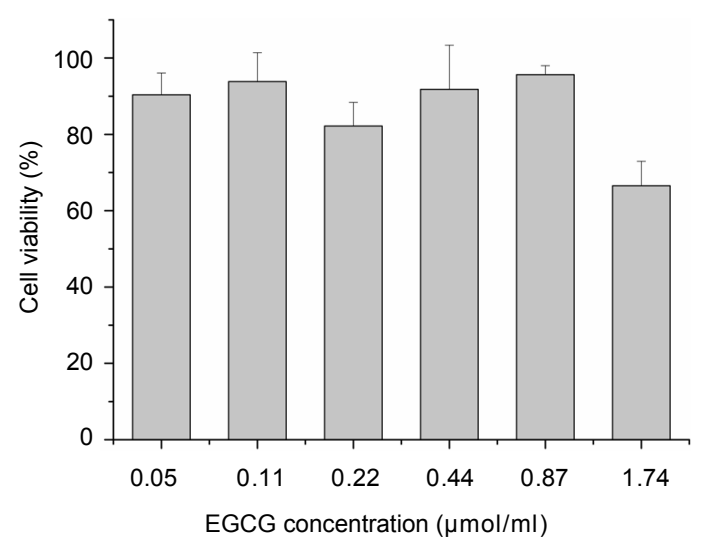

Fig. 2 Cytotoxic effects of EGCG on HepG2 2.2.15 cells with an MTT assay

The cell viability is expressed as a percentage of the control (mean $\pm \mathrm{SD}$, with $n=3$ )

\subsection{Effects of EGCG on HBV antigens}

The HBsAg and HBeAg levels in the supernatant were determined with ELISA. EGCG treatment of HepG2 2.2.15 cells resulted in a reduction in HBsAg and HBeAg secretion (Table 1) in a dosedependent manner. After treatment for $6 \mathrm{~d}, 50 \mu \mathrm{g} / \mathrm{ml}$ EGCG significantly inhibited the secretion of $\mathrm{HBsAg}$ and $\mathrm{HBeAg}$ by $53 \%$ and $44 \%$, respectively, which 
Table 1 Inhibitory effects of EGCG on the secretion of HBV antigens and expression of HBV DNA in HepG2 2.2.15 cells on Days 6 and 9

\begin{tabular}{|c|c|c|c|c|c|c|}
\hline \multirow[b]{2}{*}{ Group } & \multicolumn{2}{|c|}{ OD } & \multicolumn{4}{|c|}{ Inhibition (\%) } \\
\hline & HBsAg & $\mathrm{HBeAg}$ & HBsAg & $\mathrm{HBeAg}$ & $\begin{array}{c}\text { Extracellular } \\
\text { DNA } \\
\end{array}$ & $\begin{array}{c}\text { Intracellular } \\
\text { DNA } \\
\end{array}$ \\
\hline \multicolumn{7}{|l|}{ Day 6} \\
\hline Control & $2.71 \pm 0.15$ & $2.06 \pm 0.01$ & & & & \\
\hline $0.87 \mu \mathrm{mol} / \mathrm{ml} 3 \mathrm{TC}$ & $2.15 \pm 0.29$ & $1.02 \pm 0.32^{\mathrm{a}}$ & 21 & 57 & 95 & \\
\hline $0.11 \mu \mathrm{mol} / \mathrm{ml} \mathrm{EGCG}$ & $1.27 \pm 0.21^{\mathrm{a}}$ & $1.16 \pm 0.54^{\mathrm{a}}$ & 53 & 44 & 2 & \\
\hline $0.22 \mu \mathrm{mol} / \mathrm{ml} \mathrm{EGCG}$ & $0.56 \pm 0.20^{\mathrm{a}}$ & $0.14 \pm 0.07^{\mathrm{b}}$ & 79 & 93 & 44 & \\
\hline $0.44 \mu \mathrm{mol} / \mathrm{ml}$ EGCG & $0.64 \pm 0.23^{\mathrm{a}}$ & $0.46 \pm 0.17^{\mathrm{a}}$ & 76 & 78 & 52 & \\
\hline \multicolumn{7}{|l|}{ Day 9} \\
\hline Control & $2.33 \pm 0.22$ & $2.05 \pm 0.04$ & & & & \\
\hline $0.87 \mu \mathrm{mol} / \mathrm{ml} 3 \mathrm{TC}$ & $2.15 \pm 0.37$ & $0.87 \pm 0.14^{b}$ & 8 & 57 & 94 & 98 \\
\hline $0.11 \mu \mathrm{mol} / \mathrm{ml} \mathrm{EGCG}$ & $1.12 \pm 0.12^{\mathrm{a}}$ & $0.65 \pm 0.22^{\mathrm{b}}$ & 52 & 68 & 9 & 5 \\
\hline $0.22 \mu \mathrm{mol} / \mathrm{ml} \mathrm{EGCG}$ & $0.46 \pm 0.24^{\mathrm{b}}$ & $0.33 \pm 0.08^{\mathrm{b}}$ & 80 & 84 & 11 & 46 \\
\hline $0.44 \mu \mathrm{mol} / \mathrm{ml}$ EGCG & $0.39 \pm 0.32^{\mathrm{b}}$ & $0.19 \pm 0.08^{\mathrm{b}}$ & 83 & 91 & 69 & 39 \\
\hline
\end{tabular}

OD: optical density. ${ }^{\mathrm{a} P} P 0.05,{ }^{\mathrm{b}} P<0.01$, vs. control

was more potent at inhibiting $\mathrm{HBsAg}$ than the positive control 3TC. After treatment for $9 \mathrm{~d}$, multiple concentrations of EGCG were more potent than the positive control 3TC $(0.87 \mu \mathrm{mol} / \mathrm{ml}, 200 \mu \mathrm{g} / \mathrm{ml})$ at inhibiting $\mathrm{HBsAg}$ and $\mathrm{HBeAg}$. Based on this analysis, EGCG showed no significant differences in inhibitory activity with respect to $\mathrm{HBsAg}$ and $\mathrm{HBeAg}$ during the experiment.

\subsection{Effects of EGCG on HBV DNA expression}

After treatment with 0.11 and $0.22 \mu \mathrm{mol} / \mathrm{ml}$ EGCG, no stable decrease in the HBV DNA level in the supernatant was observed. However, after the incubation with $0.44 \mu \mathrm{mol} / \mathrm{ml}$ EGCG for 6 and $9 \mathrm{~d}$, the level of the extracellular HBV DNA had an obvious reduction, demonstrating that EGCG at $0.44 \mu \mathrm{mol} / \mathrm{ml}$ had the less potent activity than the positive control 3TC in inhibiting extracellular HBV DNA expression.

After treatment with EGCG for $9 \mathrm{~d}$, HBV DNA in cells was detected. And the results indicated that $0.11 \mu \mathrm{mol} / \mathrm{ml}$ of EGCG had no activity, and 0.22 and $0.44 \mu \mathrm{mol} / \mathrm{ml}$ of EGCG led to a slight reduction in the intracellular HBV DNA level.

\subsection{Difference between EGCG and 3TC activities}

In our study, we found that EGCG and 3TC had different activities on HBV replication. EGCG had significant effects on HBV antigens, and the activity of 3TC against HBV DNA was also significant. Aggregate analysis was conducted on the effects of EGCG on HBV antigens and DNA (Fig. 3). The results showed that $3 \mathrm{TC}$ had a strong inhibitory effect on HBV DNA, and EGCG had a potent effect on antigens. The 3TC $(0.87 \mu \mathrm{mol} / \mathrm{ml})$ had an evident effect after treatment for 6 and $9 \mathrm{~d}$, including reducing the increase in DNA levels and slightly inhibiting antigens. At $0.44 \mu \mathrm{mol} / \mathrm{ml}$ EGCG, $\mathrm{HBsAg}$ and $\mathrm{HBeAg}$ concentrations were significantly decreased, but the inhibitory effect on DNA was much weaker than that of 3TC. Only antigen levels were inhibited after treatment with $0.11 \mu \mathrm{mol} / \mathrm{ml} \mathrm{EGCG} \mathrm{for} 6 \mathrm{~d}$, and DNA inhibition was not observed until Day 9. Treatment with $0.22 \mu \mathrm{mol} / \mathrm{ml}$ EGCG for $6 \mathrm{~d}$ had an effect on DNA, but this effect disappeared on Day 9.

\section{Discussion}

HBV, a member of the Hepadnaviridae family, contains a partial double-stranded circular DNA genome of $3.2 \mathrm{~kb}$ (Pang et al., 2010). When infected with HBV, hepatocytes secrete not only antigenic components, such as $\mathrm{HBsAg}$ and $\mathrm{HBeAg}$, but also complete virion particles. The quantities of antigenic components and virion particles in the blood can 

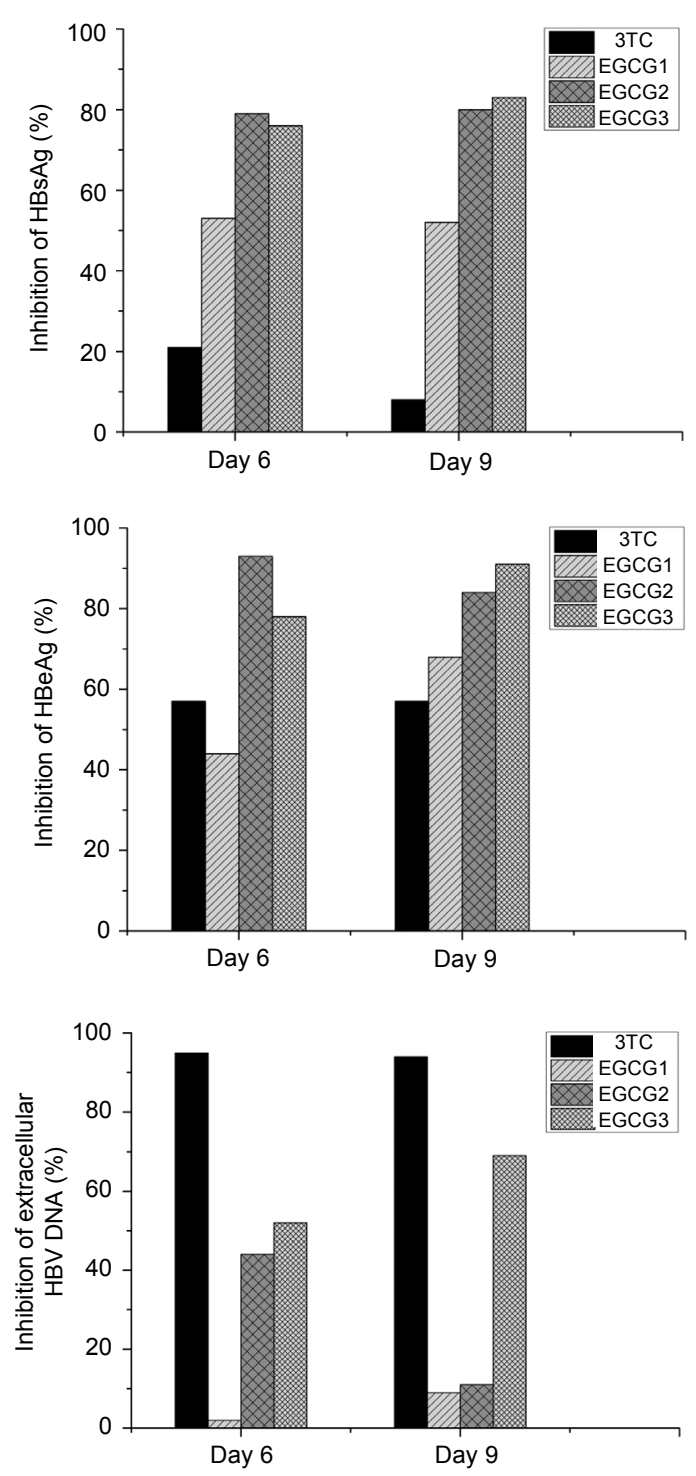

Fig. 3 Representative differential patterns of EGCG and 3TC against HepG2 2.2.15 cells

EGCG1: $0.11 \mu \mathrm{mol} / \mathrm{ml}$; EGCG2: $0.22 \mu \mathrm{mol} / \mathrm{ml}$; EGCG3: $0.44 \mu \mathrm{mol} / \mathrm{ml}$; 3TC: $0.87 \mu \mathrm{mol} / \mathrm{ml}$

indirectly reflect the severity of the HBV infection. Therefore, by detecting the levels of HBsAg, HBeAg, and HBV DNA produced by a stably HBVtransfected cell line, HepG2 2.2.15 cells, we can evaluate the potential anti-HBV activity of EGCG.

We found that EGCG and 3TC had different patterns of activity against HBV replication. The anti-HBV effect of 3TC was strong against DNA. The action of EGCG was similar to that of bufalin and cinobufagin (Cui et al., 2010), which are potent against antigens. Further research is needed to determine the similarities among the anti-HBV mechanisms of EGCG, bufalin, and cinobufagin. Different activity patterns may indicate different targets. The combination of 3TC and another target drug may increase the therapeutic effect of 3TC and/or decrease its side effects.

The worldwide treatment of hepatitis B is difficult. Currently, the price of most clinical drugs for hepatitis B treatment, such as entecavir, is very expensive, which has caused a huge economic burden in developing countries with large numbers of hepatitisinfected people, such as China. Therefore, identification of an economic and easily available drug from natural medicines can be a great prospective in alleviating the burden on the patient to a certain extent.

It has been reported that green tea, a healthy drink widely used in China, has demonstrated the activity against HBV examined on cell line HepG2N10 (Xu et al., 2008). EGCG, occupying 10\%-15\% of the total weight of green tea, is also the main component of Veregen (tea polyphenols), which was approved by the Food and Drug Administration (FDA) for the first time as the plant medicine for treatment of genital warts caused by human papilloma virus (Abramovits and Gupta, 2010). EGCG has been demonstrated to possess numerous health-promoting effects, including antiangiogenic, antiproliferative, and apoptotic effects in various tumors, and could inhibit several downstream signaling molecules in multiple signaling pathways (Hastak et al., 2003; Khan et al., 2006). It is also a promising, new, and potent anti-inflammatory agent (Singh et al., 2002; Kawai et al., 2004; 2005). Moreover, EGCG stops the progression of hepatic fibrosis by inhibiting hepatic stellate cell (HSC) activation and matrix metalloproteinase-2 activity (Zhen et al., 2007).

In this study, we investigated the anti-HBV effects of EGCG in HepG2 2.2.15 cells. Our results showed that EGCG could significantly decrease both the extracellular HBV DNA levels for 6 and $9 \mathrm{~d}$ and the intracellular HBV DNA levels for $9 \mathrm{~d}$. So the effect of EGCG may block not only the secretion, but also the overall production of viral genomic replication. The secretion of $\mathrm{HBsAg}$ and $\mathrm{HBeAg}$ compared with the control group and the results worked in both 
a dose- and time-dependent manner. The activities of EGCG against HBsAg and HBeAg were more effective than the positive control drug (3TC). To determine whether EGCG treatment could decrease the liver damage resulting from HBV infection, further study is needed to investigate the antiviral activity of EGCG in vivo.

In conclusion, we demonstrated that EGCG has a strong anti-HBV activity through decreasing the secretion of HBsAg and $\mathrm{HBeAg}$ and extracellular HBV DNA in vitro, although perhaps in such a way that the mechanism may interfere with the replication cycle of HBV DNA (Steinmann et al., 2013). Although the exact mechanism remains unclear, the data suggests the potential of EGCG as an effective anti-HBV agent with low toxicity and providing different anti-HBV activity as compared with $3 \mathrm{TC}$.

\section{Compliance with ethics guidelines}

Jing-yao PANG, Kui-jun ZHAO, Jia-bo WANG, Zhi-jie MA, and Xiao-he XIAO declare that they have no conflict of interest.

This article does not contain any studies with human or animal subjects performed by any of the authors.

\section{References}

Abramovits, W., Gupta, A.K., 2010. Veregen (sinecatechins ointment) 15\%. Skinmed, 8(1):46-49.

Ciesek, S., von Hahn, T., Colpitts, C.C., et al., 2011. The green tea polyphenol, epigallocatechin-3-gallate, inhibits hepatitis C virus entry. Hepatology, 54(6):1947-1955. [doi:10. 1002/hep.24610]

Cui, X.Y., Inagaki, Y., Xu, H.L., et al., 2010. Anti-hepatitis B virus activities of cinobufacini and its active components bualin and cinobufagin in HepG2.2.15 cells. Biol. Pharm. Bull., 33(10):1728-1732. [doi:10.1248/bpb.33.1728]

Fassina, G., Buffa, A., Benelli, R., et al., 2002. Polyphenolic antioxidant (-)-epigallocatechin-3-gallate from green tea as a candidate anti-HIV agent. AIDS, 16(6):939-941. [doi:10.1097/00002030-200204120-00020]

Feld, J., Locarnini, S., 2002. Antiviral therapy for hepatitis B virus infections: new targets and technical challenges. $J$. Clin. Virol., 25(3):267-283. [doi:10.1016/S1386-6532(02) 00107-5]

Harada, S., Haneda, E., Maekawa, T., et al., 1999. Casein kinase II (CK-II)-mediated stimulation of HIV-1 reverse transcriptase activity and characterization of selective inhibitors in vitro. Biol. Pharm. Bull., 22(10):1122-1126. [doi:10.1248/bpb.22.1122]
Hastak, K., Gupta, S., Ahmad, N., et al., 2003. Role of p53 and $\mathrm{NF}-\kappa \mathrm{B}$ in epigallocatechin-3-gallate-induced apoptosis of LNCaP cells. Oncogene, 22(31):4851-4859. [doi:10.1038/ sj.onc.1206708]

Kawai, K., Tsuno, N.H., Kitayama, J., et al., 2004. Epigallocatechin gallate attenuates adhesion and migration of $\mathrm{CD}^{+} \mathrm{T}$ cells by binding to CD11b. J. Allergy Clin. Immunol., 113(6):1211-1217. [doi:10.1016/j.jaci.2004.02.044]

Kawai, K., Tsuno, N.H., Kitayama, J., et al., 2005. Epigallocatechin gallate induces apoptosis of monocytes. $\mathrm{J}$. Allergy Clin. Immunol., 115(1):186-191. [doi:10.1016/j.jaci. 2004.10.005]

Khan, N., Afaq, F., Saleem, M., et al., 2006. Targeting multiple signaling pathways by green tea polyphenol (-)-epigallocatechin-3-gallate. Cancer Res., 66(5):25002555. [doi:10.1158/0008-5472.CAN-05-3636]

Nakane, H., Ono, K., 1989. Differential inhibition of HIVreverse transcriptase and various DNA and RNA polymerases by some catechin derivatives. Nucl. Acids Symp. Ser., (21):115-116.

Pang, R., Tao, J.Y., Zhang, S.L., et al., 2010. In vitro antiviral activity of lutein against hepatitis B virus. Phytother. Res., 24(11):1627-1630. [doi:10.1002/ptr.3155]

Park, N.H., Song, I.H., Chung, Y.H., 2006. Chronic hepatitis B in hepatocarcinogenesis. J. Postgrad. Med. J., 82(970): 507-515. [doi:10.1136/pgmj.2006.047431]

Perrillo, R.P., 2005. Current treatment of chronic hepatitis B: benefits and limitations. Semin. Liver Dis., 25(S1):20-28. [doi:10.1055/s-2005-915647]

Singh, R., Ahmed, S., Islam, N., et al., 2002. Epigallocatechin3 -gallate inhibits interleukin-1 $\beta$-induced expression of nitric oxide synthase and production of nitric oxide in human chondrocytes: suppression of nuclear factor kappaB activation by degradation of the inhibitor of nuclear factor kappaB. Arthritis Rheum., 46(8):2079-2086. [doi:10. 1002/art.10443]

Steinmann, J., Buer, J., Pietschmann, T., et al., 2013. Antiinfective properties of epigallocatechin-3-gallate (EGCG), a component of green tea. Brit. J. Pharmacol., 168(5): 1059-1073. [doi:10.1111/bph.12009]

Stickel, F., Schuppan, D., 2007. Herbal medicine in the treatment of liver diseases. Dig. Liver Dis., 39(4):293-304. [doi:10.1016/j.dld.2006.11.004]

Xu, J., Wang, J., Deng, F., et al., 2008. Green tea extract and its major component epigallocatechin gallate inhibits hepatitis B virus in vitro. Antivir. Res., 78(3):242-249. [doi:10. 1016/j.antiviral.2007.11.011]

Yamaguchi, K., Honda, M., Ikigai, H., et al., 2002. Inhibitory effects of (-)-epigallocatechin gallate on the life cycle of human immunodeficiency virus type 1 (HIV-1). Antivir. Res., 53(1):19-34. [doi:10.1016/S0166-3542(01)00189-9] 
Zhang, L., Wang, G., Hou, W., et al., 2010. Contemporary clinical research of traditional Chinese medicines for chronic hepatitis B in China: an analytical review. Hepatology, 51(2):690-698. [doi:10.1002/hep.23384]
Zhen, M.C., Wang, Q., Huang, X.H., et al., 2007. Green tea polyphenol epigallocatechin-3-gallate inhibits oxidative damage and preventive effects on carbon tetrachlorideinduced hepatic fibrosis. J. Nutr. Biochem., 18(12):795805. [doi:10.1016/j.jnutbio.2006.12.016]

\section{中文梅要:}

\section{本文题目：绿茶多酚表没食子儿茶素没食子酸酯（EGCG）体外对抗乙肝病毒复制的能力}

Green tea polyphenol, epigallocatechin-3-gallate, possesses the antiviral activity necessary to fight against the hepatitis $B$ virus replication in vitro

研究目的: 乙肝是尚未解决的公众健康问题, 需要开发新型抗病毒药物。本研究拟从天然植物绿茶中寻 找有效、经济、毒副作用低的抗乙肝病毒药物。

创新要点: 首次以HepG2 2.2.15细胞为载体, 发现EGCG对乙肝病毒HBsAg、HBeAg和HBV DNA的选择 性作用。

研究方法: 采用酶联免疫吸附实验 (ELISA) 检测细胞上清中HBsAg和HBeAg的含量, 采用反转录聚合 酶链反应（RT-PCR）检测上清和细胞内HBV DNA的含量。

重要结论: EGCG的浓度在0.11 0.44 $\mu \mathrm{mol} / \mathrm{ml}$ （即50 200 $\mu \mathrm{g} / \mathrm{ml}$ ）的范围内能有效抑制 HepG2 2.2.15细胞 中 HBsAg和 $H B e A g$ 的分泌, 其效果甚至优于浓度为 $0.87 \mu \mathrm{mol} / \mathrm{ml}$ （即 $200 \mu \mathrm{g} / \mathrm{ml}$ ）的拉米夫定 (3TC) , 并且具有时间和剂量依赖性。同时, EGCG也能抑制胞外HBV DNA的表达。研究 结果表明, EGCG具有良好抗病毒活性和低毒副作用, 有望开发成为一种新的抗病毒药物。

关键词组: EGCG; 乙肝病毒 (HBV) ; 抗病毒; HepG2 2.2.15 细胞; 拉米夫定 